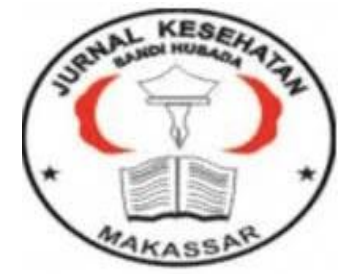

Jurnal Ilmiah Kesehatan Sandi Husada

hhttps://akper-sandikarsa.e-journal.id/JIKSH

Volume 9, Nomor 2, Desember 2020, pp 702-707

p-ISSN: 2354-6093 dan e-ISSN: 2654-4563

DOI: $10.35816 /$ jiskh.v10i2.373

\title{
Hubungan Faktor Keturunan Dengan Kanker Payudara DI RSUD Abdoel Moeloek
}

Relationship of Children's History Factor with Breast Cancer in Dr. Abdoel Moeloek Hospital

\author{
Ariq Naupal Azmi 1, Bambang Kurniawan², Andi Siswandi ${ }^{3}$, Ade Utia Detty ${ }^{4}$ \\ ${ }_{1}^{1}$ Program Pendidikan Dokter, Fakultas Kedokteran, Universitas Malahayati \\ 2Departemen Reproduksi dan Ginekologi Rumah Sakit Bintang Amin Bandar Lampung \\ ${ }^{3}$ Departemen Ilmu Bedah, Rumah Sakit DKT Bandar Lampung \\ ${ }^{4}$ Departemen Reproduksi Fakultas Kedokteran, Universitas Malahayati
}

\section{Artikel info}

Artikel history:

Received; Juli 2020

Revised: Agustus 2020

Accepted; Agustus 2020

\begin{abstract}
Abstrak
Kanker merupakan salah satu penyakit tidak menular yang menjadi masalah kesehatan masyarakat, kanker payudara dapat bersifat sporadis, familial dan turun temurun. Tujuan: Untuk mengetahui apakah ada hubungan faktor riwayat hereditas dengan kanker payudara di RSUD Dr. Abdul Moeloek. Penelitian analitik observasional dengan pendekatan cross sectional. Sampel dalam penelitian ini adalah seluruh pasien kanker payudara yang tercatat pada rekam medik 2019 diambil secara total sampling. Analisis data menggunakan analisis univariat dan analisis bivarait menggunakan Chi-Squar. Hasil: Frekuensi diketahui distribusi riwayat herediter pada pasien kanker payudara terbanyak dengan riwayat keluarga kanker payudara sebesar 61,0\%. Diketahui ada hubungan yang signifikan antara faktor riwayat herediter dan kanker payudara (nilai p: 0,000; 0R: $10,9)$.
\end{abstract}

\begin{abstract}
.
Cancer is one of the uncontagious diseases that become a matter of public health, breast cancer can be sporadic, familial and hereditary. Objectives: To find out if there is a history factor relationship of heredity with breast cancer in the Dr. Abdul Moeloek Hospital. Observational analytic research with cross sectional approaches. The sample in this study is that all breast cancer patients recorded in 2019 medical records were taken in total sampling. Analysis of data using univariate analysis and bivarait analysis using ChiSquar. Results: Known frequency distributions of hereditary history in breast cancer patients most with a family history of breast cancer amounted to $61.0 \%$. There is known a significant link between the hereditary history factor and breast cancer ( $p$ value: 0.000; 0R: 10.9)
\end{abstract}




\begin{tabular}{lr}
\hline Keywords: & $\begin{array}{r}\text { Coresponden author: } \\
\text { Riwayat Keturunan; }\end{array}$ \\
Kanker Payudara; & Email: ariqnaufalazmi@gmail.com \\
& artikel dengan akses terbuka dibawah lisensi CC BY 4.0 \\
\hline
\end{tabular}

\section{Pendahuluan}

Kanker payudara adalah keganasan pada payudara yang berasal dari sel kelenjar, saluran kelenjar, serta jaringan penunjang payudara, namun tidak termasuk kulit payudara. Sel kanker dapat timbul apabila telah terjadi mutasi genetik sebagai akibat dari adanya kerusakan DNA pada sel normal. Laporan terbaru yang dirilis oleh International Agency for Research on Cancer (IARC) menyebutkan bahwa pada tahun 2018 tercatat 18,1 juta kasus baru dengan angka kematian sebesar 9,6 juta kematian, dimana 1 dari 5 laki-laki dan 1 dari 6 perempuan di dunia mengalami kejadian kanker. Kanker payudara merupakan kanker terbesar yang mengakibatkan kematikan pada perempuan, tercatat kematian karena kanker payudara di dunia sebesar $14 \%$ per tahun. Serang kanker yang massif ini membuat WHO memprediksi bahwa kanker payudara menjadi penyebab kematian pertama pada wanita setelah kanker serviks pada abad ini (DeSantis, etal, 2014).

Kanker payudara merupakan salah satu jenis kanker yang sering terjadi pada perempuan di Indonesia. Kanker payudara memiliki kontribusi sebesar $30 \%$ dan merupakan jenis kanker yang paling mendominasi di Indonesia, mengalahkan kanker leher rahim atau kanker serviks yang berkontribusi sebesar 24\%. Data Riskesdas tahun 2019 menyebutkan bahwa prevalensi kejadian kanker payudara di Indonesia yaitu sebesar 42,1 per 100.000 penduduk dengan rata-rata kematian 17 per 100.000 penduduk. Prevalensi tumor/kanker di Indonesia menunjukkan adanya peningkatan dari 1,4 per 1000 penduduk di tahun 2013 menjadi 1,79 per 1000 penduduk pada tahun 2018 (Eismann et al., 2019).

Penyebab spesifik kanker payudara masih belum diketahui, Adapun faktor risiko terjadinya kanker payudara, yaitu usia $>50$ tahun, adanya riwayat kanker payudara pada keluarga, obesitas, kebiasaan merokok, konsumsi alkohol, pemakaian alat kontrasepsi hormonal dalam jangka waktu yang lama, paparan radiasi, tidak pernah melahirkan atau melahirkan pertama kali pada usia lebih dari 35 tahun, serta tidak menyusui. Menopause yang terlambat, yaitu pada usia $>50$ tahun, dan menarche dini, yaitu usia pertama kali mengalami menstruasi < 12 tahun juga merupakan faktor risiko dari kanker payudara. Dari faktor risiko tersebut, riwayat keluarga serta usia menjadi faktor terpenting. Riwayat keluarga yang pernah mengalami kanker payudara meningkatkan risiko berkembangnya penyakit ini. Data WHO menunjukan bahwa $78 \%$ kanker payudara terjadi pada wanita usia 50 tahun ke atas. Sedangkan 6\%-nya pada usia kurang dari 40 tahun. Namun banyak juga para wanita yang berusia 30-an terkena kanker yang mematikan ini (DeSantis et al., 2014).

Kanker merupakan salah satu penyakit tidak menular yang menjadi masalah kesehatan masyarakat. Pada wanita, kemungkinan terkena kanker payudara 100 kali lipat dibandingkan pada pria (Prasetyowati \& Katharina, 2017). Kanker payudara dapat sporadis, familial dan herediter. Kanker payudara sporadis berarti penderita tidak memiliki riwayat keluarga yang menderita kanker payudara paling tidak sampai 2 degree seperti orang tua, paman atau bibi dan kakek atau nenek, sebaliknya kanker payudara familial berarti terdapat riwayat keluarga yang menderita kanker payudara termasuk lebih dari 1 atau 2 degree. Penderita yang mempunyai riwayat kanker payudara familial, penderita kanker payudara usia muda (kurang dari 40 tahun), Riwayat keluarga merupakan faktor risiko kejadian kangker payudara. Wanita yang memiliki riwayat 
keluarga memiliki risiko 2 kali menderita kanker payudara dibanding wanita yang tidak memiliki riwayat keluarga. Hal ini disebabkan oleh mutasi gen BRCA1 dan BRCA2, kedua gen ini yang $90 \%$ bertanggung jawab sebagai penyebab kanker ovarium yang diturunkan kepada keturunan yang menderita kanker ovarium, sedangkan angka harapan hidup penderita yang membawa gen mutasi BRCA1 dan BRCA2 sebesar 15\%-60\% sehingga sangat diperlukan dilakukan skrining kepada penderita yang membawa gen mutasi BRCA1 dan BRCA2 (Eismann et al., 2019).

\section{Metode}

Jenis pada penelitian ini adalah penelitian analitik observasional retrospektif dengan pendekatan cross sectional yang bertujuan unutuk mengetahui hubungan faktor riwayat keturunan dengan kanker payudara di RSUD Dr.Abdul Moeloek. Populasi pada penelitian ini adalah seluruh pasien kanker payudara yang tercatat di data rekam medik RS. Dr. Abdul Moeloek tahun 2019 yang sesuai kriteria inklusi sebanyak 77 responden. Pengumpulan data skunder dan primer dengan menggunakan teknik total sampling. Kriteria inklusi pada penelitian ini semua pasien kanker payudara yang terdiagnosa dan tercatat di rekam medik RS. Dr. Abdul Moeloek Bandar Lampung Tahun 2019. Variabel independent dalam penelitian ini adalah kanker payudara, variabel dependent dalam penelitian ini adalah riwayat keturunan. Pengolahan data menggunakan analisis univariat untuk mengatahui prevalensi variabel independen dan variabel dependen dan analisis bivariate untuk menetukan tingkah hubungan variabel independen dengan dependen

\section{Hasil Dan Pembahasan}

Tabel 1 Distribusi Frekuensi Riwayat Keturunan Pasien Kanker Payudara

\begin{tabular}{|c|c|c|}
\hline Riwayat Keturunan & $\mathbf{F}$ & $(\%)$ \\
\hline Iya & 47 & 61,0 \\
\hline Tidak & 30 & 39,0 \\
\hline Jumlah & 77 & 100 \\
\hline
\end{tabular}

Sumer: Primer, 2019

Tabel 2 Hubungan Faktor Riwayat Keturunan Dengan Kejadian Kanker Payudara

\begin{tabular}{|c|c|c|c|c|c|c|c|c|}
\hline \multirow{3}{*}{$\begin{array}{l}\text { Riwayat } \\
\text { Keluarga }\end{array}$} & \multicolumn{4}{|c|}{ Kejadian Kanker Payudara } & \multicolumn{2}{|c|}{ Total } & \multirow{3}{*}{$\begin{array}{c}\text { OR } \\
95 \% \mathrm{CI} \\
\text { (lower- } \\
\text { upper) }\end{array}$} & \multirow{3}{*}{$\begin{array}{c}p- \\
\text { value }\end{array}$} \\
\hline & \multicolumn{2}{|c|}{$\begin{array}{c}\text { hasil } \\
\text { mikroskopik } \\
\text { histopatologi } \\
(+)\end{array}$} & \multicolumn{2}{|c|}{$\begin{array}{c}\text { hasil } \\
\text { mikroskopik } \\
\text { histopatologi } \\
(-)\end{array}$} & \multirow[b]{2}{*}{$\mathbf{N}$} & \multirow[b]{2}{*}{$\%$} & & \\
\hline & $\mathbf{N}$ & $\%$ & $\mathbf{N}$ & $\%$ & & & & \\
\hline Iya & 42 & 89,4 & 5 & 10,6 & 47 & 100 & & \\
\hline Tidak & 13 & 43,3 & 17 & 56,7 & 30 & 100 & $10,9(1,2-3,5)$ & 0,000 \\
\hline Jumlah & 55 & 71,4 & 22 & 28,6 & 77 & 100 & & \\
\hline
\end{tabular}

Sumer: Primer, 2019

Berdasarkan hasil penelitian dari 77 responden tentang distribusi frekuensi riwayat keturunan seperti tabel 1 diatas menunjukkan paling banyak memiliki riwayat keluarga kanker payudara sebanyak 61,0\% tabel.1.

Berdasarkan uji statistik dengan uji chi squareberdasarkan tabel 2 diaats didapatkan $\mathrm{p}$ value : $0,000(\alpha<0,05)$ yang artinya Ha di terima sehingga dapat disimpulkan terdapat hubungan yang signifikan antara riwayat keluarga dengan kejadian kanker payudara di 
RSUD Abdul Moeleok Tahun 2019, dimana nilai OR didapatkan 10,9 dengan confidence interval (CI) 95\% sebesar (1,2-3,5), artinya responden dengan riwayat keluarga kanker payudara meningkatkan risiko kejadian kanker payudara sebesar 10 kali daripada responden tanpa riwayat keluarga kanker payudara. Dimana nilai OR diantara nilai CI dengan selisih OR dengan Upper 3,5 dan selisih OR dengan Lower 1,2. Hal ini menunjukkan bahwa rentang tingkat kepercayaan yang tinggi tabel.2.

Hasil penelitian sejalan dengan teori yang menyebutkan bahwa kanker payudara merupakan penyakit kanker familial (Sindroma Li Fraumeni/LFS). Tujuh puluh lima persen dari sindroma tersebut disebabkan adanya mutasi pada gen p53. Gen p53 merupakan gen penekan tumor (suppressor gene) mutasi pada gen p53 menyebabkan fungsi sebagai gen penekan tumor mengalami gangguan sehingga sel akan berproliferasi secara terus menerus tanpa adanya batas kendali. Seseorang akan memiliki risiko terkena kanker payudara lebih besar bila pada anggota keluarganya ada yang menderita kanker payudara atau kanker ovarium. Kanker payudara dihubungkan dengan adanya riwayat kanker pada keluarga. Keluarga yang memiliki gen BRCA1 yang diturunkan memiliki risiko terkena kanker payudara lebih besar (Eismann et al., 2019).

Hasil penelitian sejalan dengan penelitian (Murphy et al., 2011) yang menunjukkan bahwa kejadian kanker payudara dengan riwayat keluarga sebesar $60 \%$. Penelitain lain sejalan yaitu penelitian (Surbakti, 2013) tetang hubungan riwayat keturunan dengan kejadian kanker payudara, menyatakan bahwa dari 85 responden, 56,1\% memiliki riwayat keturunan kanker payudara. Hasil pun sejalan dengan penelitian (Prasetyowati \& Katharina, 2017) penelitian tentang faktor-faktor kejadian kanker payudara terhadap 78 responden, didapatkan bahwa 31,5\% responden kasus kanker payudara memiliki riwayat keluarga kanker payudara. hal ini disebabkan karena riwayat keluarga merupakan komponen yang penting dalam riwayat penderita. Terdapat resiko keganasan pada wanita yang keluarganya menderita kanker payudara. Pada studi genetik ditemukan bahwa kanker payudara berhubungan dengan gen tertentu. Apabila terdapat BRCA 1, yaitu suatu gen suseptibilitas (resiko untuk menderita) kanker payudara, probabilitas atau peluang untuk menjadi kanker payudara adalah sebesar 60\%.5 Penelitian serupa yaitu hasil penelitian (Anggorowati, 2013). (Prasetyowati \& Katharina, 2017)menunjukan bahwa wanita dengan riwayat keluarga pernah menderita kanker payudara lebih berisiko terkena kanker payudara dibandingkan wanita yang tidak ada riwayat kanker payudara pada keluarga. Apabila dilakukan pemeriksaan genetik terhadap darah dan hasil menunjukan positif, maka dapat meningkatkan peluang terkena kanker payudara pada keturunannya 2 hingga 3 kali lebih tinggi. Hasil penelitian (Sari \& Afni Amran, 2019) tidak terdapat hubungan antara riwayat penggunaan kontrasepsi oral dengan kejadian kanker payudara $(\mathrm{p}=0,1)$ Kesimpulan penelitian ini adalah tidak terdapat hubungan riwayat penggunaan kontrasepsi oral dengan kejadian kanker payudara pada wanita premenopause.

Ditemukan bahwa pasien dengan diagnosis kanker. Distribusi tertinggi berdasarkan umur yaitu pada kelompok 46-55 tahun dengan persentase $28.6 \%$, berdasarkan jenis kelamin yaitu laki-laki dengan persentase $65 \%$, berdasarkan tipe histopatologi yaitu Nonkeratinizing Cell Carcinoma -Undifferentiated subtypedengan persentase $71.4 \%$ dan berdasarkan stadium klinis yaitu Stadium III, yaitu sebanyak 22 kasus atau $63.3 \%$. Karakteristik histopatologi dan stadium klinis kanker nasofaring dan didapatkan distribusi frekuensi kanker (Kuswandi, dkk, 2020). Terdapat penurunan rerata kadar trombosit tertinggi terjadi pada siklus keenam sebesar 54,186/mm3dengan simpangan baku sebesar 16,127/mm3, dan didapatkan toksisitas trombosit derajat satu pada siklus ke-5 dan ke-6 masing-masing sebanyak 3(4,3\%) dan 18(25,7\%)dan yang 
mengalami derajat dua pada siklus ke-5 dan ke-6 masing-masing sebanyak $1(1,4 \%)$ dan 10(14,3\%) (Yusmaidi, dkk, 2020).

Bahwa terdapat enam faktor yang memiliki hubungan bermakna dengan keterlambatan penderita kanker payudara dalam melakukan pemeriksaan awal ke pelayanan kesehatan yaitu tingkat pendidikan (tingkat pendidikan rendah $\mathrm{p}=0,001 ; 0 \mathrm{R}$ 5,67 dan tingkat pendidikan sedang, tingkat pengetahuan (tingkat pengetahuan kurang dan tingkat pengetahuan cukup, keterjangkauan biaya, keterpaparan informasi/media massa, dukungan suami/keluarga, dan perilaku deteksi dini (tidak pernah SADARI (pemeriksaan payudara sendiri) dan tidak rutin SADARI. Keterlambatan penderita kanker payudara melakukan pemeriksaan awal ke pelayanan kesehatan di Indonesia mencapai lebih dari 80\%. Hal ini mengakibatkan kejadian kanker payudara banyak yang ditemukan pada stadium lanjut (Dyanti \& Suariyani, 2016).

Kanker pankreas sulit didiagnosis pada tahap awal dan umumnya memiliki prognosis yang buruk. Reseksi bedah adalah satu-satunya pengobatan yang berpotensi menyembuhkan untuk karsinoma pankreas. Untuk meningkatkan prognosis penyakit ini, penting untuk mendeteksi tumor pada tahap awal. Kurangnya penanda tumor yang sensitive dan spesifik untuk diagnosis dini memiliki kontribusi besar terhadap prognosis buruk. Untuk itu sangat diperlukan sekali diagnosis di ni kanker pankreas melalui biomarker berupa mesothelin yang dapat ditemukan di darah dan urine. Mesothelin adalah glikoprotein yang diekspresikan pada sel mesothelial normal namun diekpresikan berlebih pada kanker pankreas. Cara memeriksanya kadar mesothelin yang ada di darah dapat menggunakan ELISA dan untuk yang berada diurine dapat menggunakanspektofotometri (Hanriko, 2019).

Berdasarkan hasil analisis statistic menggunakan uji korelasi spearman's yang menunjukkan hasil p-value sebesar 0,024 dan 0.047 ( $\mathrm{p}$-value $<0,05$ ) yang berarti bahwa terdapat hubungan yang bermakna antara leukosit dan kadar bilirubin total pada penderita ikterus obstruktif yang disebabkan oleh tumor pankreas. Ada hubungan leukosit dan kadar bilirubin total pada penderita ikterus obstruktif yang disebabkan oleh tumor pancreas (Fadhilah, 2020).

\section{Simpulan Dan Saran}

Diketahui terdapat hubungan yang signifikan antara faktor riwayat keturunan dengan kanker payudara (p value: 0,000; 0R: 10,9). Diharapkan penelitian ini dapat dapat memberikan pengetahuan bagi mahasiswa-mahasiswi mengenai riwayat keturuan terhadap kejadian kanker payudara.

\section{Daftar Rujukan}

Anggorowati, L. (2013). Faktor risiko kanker payudara wanita. KEMAS: Jurnal Kesehatan Masyarakat, $8(2)$.

DeSantis, C., Ma, J., Bryan, L., \& Jemal, A. (2014). Breast cancer statistics, 2013. CA: A Cancer Journal for Clinicians, 64(1), 52-62.

Dyanti, G. A. R., \& Suariyani, N. L. P. (2016). Faktor-Faktor Keterlambatan Penderita Kanker Payudara dalam Melakukan Pemeriksaan Awal ke Pelayanan Kesehatan. KEMAS: Jurnal Kesehatan Masyarakat, 11(2), 276-284.

Eismann, J., Heng, Y. J., Fleischmann-Rose, K., Tobias, A. M., Phillips, J., Wulf, G. M., \& Kansal, K. J. (2019). Interdisciplinary management of transgender individuals at risk for breast cancer: case reports and review of the literature. Clinical Breast Cancer, 19(1), e12-e19. 
Fadhilah, L. N. (2020). Leukosit dan Kadar Bilirubin Total pada Ikterus Obstruktif yang Disebabkan oleh Tumor Pankreas. Jurnal Ilmiah Kesehatan Sandi Husada, 11(1), 183-189.

Hanriko, R. (2019). Mesothelin Sebagai Biomarker Deteksi Dini Kanker Pankreas. Jurnal Ilmiah Kesehatan Sandi Husada, 10(2), 143-150.

Kuswandi, A., Kuswandi, N. H., Kasim, M., \& Wulandari, M. (2020). Karakteristik Histopatologi dan Stadium Klinis Kanker Nasofaring. Jurnal Ilmiah Kesehatan Sandi Husada, 11(1), 243-251.

Murphy, G. S., Szokol, J. W., Greenberg, S. B., Avram, M. J., Vender, J. S., Nisman, M., \& Vaughn, J. (2011). Preoperative Dexamethasone Enhances Quality of Recovery after Laparoscopic CholecystectomyEffect on In-hospital and Postdischarge Recovery Outcomes. Anesthesiology: The Journal of the American Society of Anesthesiologists, 114(4), 882-890.

Prasetyowati, P., \& Katharina, K. (2017). Faktor-Faktor Yang Berhubungan Dengan Kejadian Kanker Payudara Di RSUD Dr. H. Abdul Moeloek Provinsi Lampung. Jurnal Kesehatan Metro Sai Wawai, 7(1), 75-84.

Sari, N., \& Afni Amran, V. (2019). Hubungan Penggunaan Kontrasepsi Oral dengan Kanker Payudara Wanita Premenopause. Jurnal Ilmiah Kesehatan Sandi Husada, 10(2), 132-137.

Surbakti, E. (2013). Hubungan Riwayat Keturunan Dengan Terjadinya Kanker Payu-dara Pada Ibu Di RSUP H. Adam Malik Medan. Precure, 1, 160007.

Yusmaidi, Y., Rafie, R., Nur, M., \& Nabilah, B. (2020). Derajat Toksisitas Trombosit pada Penderita Kanker Kolorektal yang Mendapat Kemoterapi CapeOX. Jurnal Ilmiah Kesehatan Sandi Husada, 11(1), 313-320. 